\title{
MODEL STUDI HUKUM KELUARGA ISLAM: MENCARI PIJAKAN, MERESPON TANTANGAN ZAMAN
}

\author{
J.M. Muslimin \\ Ketua Program Studi Strata Dua Sekolah Pascasarjana \\ UIN Syarif Hidayatullah Jakarta \\ pisbar2000@yahoo.com
}

\begin{abstract}
This article offers a contextual study model on the Islamic law in Indonesia where Muslim people expect their religion to be able to adapt to the complex current developments, such as administrative affairs and state legislations, in the country. This issue also takes place globally, particularly in the Muslim world. Here, this paper delves this problem by exploring some factors that lead people to partake that expectation.
\end{abstract}

Keywords: syariah, syuro, sunni, khilafah

\section{A. 'BERSYARIAH' DAN KONTEKS GLOBAL}

Seperti yang kita lihat dan rasakan bersama, dewasa ini tuntutan untuk diterapkannya syariah Islam terus menggema di berbagai belahan dunia Muslim. Jika dikategorisasikan, maka setidaknya ada tiga model tuntutan dan aplikasi syariah Islam di berbagai negara Muslim.

Pertama, model aplikasi yang ekstensif dan berangkat dari asumsi yang ekstra maksimalis. Model yang seperti ini dapat kita temukan di negara seperti Afghanistan pada zaman Taliban. Hasilnya, ternyata syariah dirasakan kurang bersahabat dengan peradaban; beberapa peninggalan sejarah monumental atas nama syariah harus diruntuhkan karena dianggap simbol paganisme, klenik, takhayyul dan praktek-praktek sesat. Perempuan terpaksa dipasung betulbetul pada wilayak domestik yang sangat restriktif; dapur, sumur, kasur. Minoritas non-Muslim sering menjadi bulan-bulanan dan dianggap sebagai warganegara kelas dua dengan hak yang harus dibedakan dengan warga kebanyakan. Pergaulan dengan komunitas internasional selalu dibarengi dengan kecurigaan sangat tinggi dan fleksibilitas serta apresiasi yang sangat rendah. Timbul faksi dan fraksi internal di kalangan umat Islam yang sangat 
tajam dikarenakan adanya rivalitas kesucian antar kelompok Muslim sendiri yang sangat tinggi. Sistim sosial dan politik dibangun dengan sangat tertutup, elitis dan tidak jarang otoriter dan diktator. Prinsip syuro tidak pernah dijalankan dengan baik dan hanya merupakan kamuflase dari cara menutupi kepentingan elit oligarkis yang sangat eksklusif. ${ }^{1}$

Kedua, model aplikasi yang literal dan tekstual. Model ini seperti dicontohkan oleh praktek yang ada di Kerajaan Saudi Arabia. Di dalam model yang seperti ini maka syariah biasanya dipasang sebagai simbol-simbol utama dalam praktek sehari-hari yang hanya menyentuh wilayah permukaan. Di bawah permukaan dan dalam lingkup tertutup, sebenarnya syariah tidak pernah betul-betul menjadi cita dan agenda. Sistem pemerintahan dijalankan dengan tertutup, oligarkis, monarkis dan cenderung arbriter. Nalar publik dan partisipasinya ditutup rapat. ${ }^{2}$ Di samping kekuasaan kerjaan duniawi diangkat seorang Imam/Mufti yang pada hakekatnya hanya dijadikan sebagai penjaga gawang semu dari penerapan syariah yang sesungguhnya. Beruntung, negara ini kaya raya dan memiliki sumber alam yang melimpah ruah, sehingga dapat meminimalisir adanya pergolakan dan memainkan kartu keamanan yang ketat dengan membangun aliansi dan kerjasama taktis dan strategis dengan negara Barat yang hegemonik. Sehingga, sebagai bangsa dan negara dapat terus melangsungkan roda organisasi pemerintahannya. Meski harus terus ditopang dan dibangun dengan ongkos petrodollar.

Ketiga, model aplikasi syariah yang dialogis, terbuka dan gradual. Asumsi dari pemerintahan yang mengagendakan hal ini adalah terciptanya partisipasi publik yang maksimal, tereksplorasinya syariah yang prinsipil dan orisinil, teraktualisasinya nilai syariah yang memayungi semua pihak dan orang, tanpa terkecuali. Negara yang menjalankan model ini, diantaranya adalah Pakistan dan Indonesia. Syariah dalam konstitusi dan perundangundangan tetap menjadi sumber acuan nilai dan etika. Tetapi penerapan syariah berjalan secara mengalir, alami dan melalui serangkaian debat dan partisipasi publik yang meluas. Meski terasa sangat lambat dan mungkin

\footnotetext{
${ }^{1}$ Bandingkan, Farhat J. Ziadeh, "Criminal Law" in The Encyclopedia of the Islamic World"; Matthew Lipman "Islamic Criminal Law and Procedure: Religious Fundamentalism vs Modern Law" in Boston College of International and Comparative Law Review, vol. 12, Issue 1, 12-1-1989; Abdurrahman al-Muala"Crimes and Punishment in Islam", www.islamtoday.com, last modified 16 oct 2011; Rudolp Peter, Crime and Punishment in Islamic Law: Theory and Practice from the Sixteenth to the Twenty-first Century, UK: Cambridge Univ. Press, 2005.

${ }^{2}$ Ziadeh "Criminal Law"; Peter, Crime and Punishment.
} 
malah cenderung berjalan di tempat, tetapi penerapan syariah dengan model ini terlihat menjadi fenomena yang meyakinkan dan menentramkan. Apa paradigma yang melandasi model yang ketiga ini? Setidaknya beberapa uraian berikut bisa menjadi titik acuannya.

\section{B. Doktrin dan Realitas Indonesia}

Diantara tuntutan politik yang semakin menggema di berbagai belahan dunia muslim (tak terkecuali Indonesia) adalah tuntutan untuk diterapkannya syariah di dalam administrasi dan tata perundang-undangan negara.

Jika dianalisa secara seksama, setidaknya ada dua akar penyebab utama yang saling terkait dari munculnya arus tuntutan tersebut: akar internal dogmatis dan kesejarahan masyarakat Islam itu sendiri serta akar eksternal yang lebih merupakan respon-situasional terhadap tantangan lingkungan sosio-politik kontemporer yang dihadapi oleh masyarakat muslim umumnya.

Menyangkut akar internal dogmatis dan kesejarahan umat Islam, setidaknya ada empat faktor penyebab;

Pertama, dibanding dengan corak pemikiran nabi-nabi non-semitik, corak pemikiran Nabi Semitik memiliki aksentuasi pada upaya untuk mengkonkritkan misi kenabian pada realitas sejarah (history-oriented accentuation). Orientasi ini pada gilirannya menginspirasikan adanya usaha yang terus menerus untuk membawa cita ideal kemasyarakatan religius ke dalam aneka wadah dan waktu dari sejarah nyata kemanusiaan. ${ }^{3}$ Salah satu piranti yang sangat efektif untuk proses penopangan cita ideal tersebut adalah piranti hukum. $^{4}$

Kedua, seperti halnya Nabi Musa dan Daud, Nabi Muhammad dikategorikan sebagai 'nabi bersenjata' (armed prophet). Secara geopolitik, ekspansi dan infiltrasi Islam berjalan begitu cepat. Tidak lama setelah kurang lebih 30 tahun pasca Islam pertama kali diperkenalkan oleh Nabi Muhammad di Mekkah, kemudian Madinah, hampir seluruh jazirah Arab telah tunduk

${ }^{3}$ Marshall G.S. Hodgson, The Venture of Islam, Chicago: The University of Chicago Press, 1974, Vol. 1, hal. 117-118; Bandingkan dengan Nurcholish Madjid, Islam: Doktrin dan Peradaban, Jakarta Paramadina, 2000.

${ }^{4}$ Bandingkan, Lawrence M. Friedmann, The Legal System: A Social Science Perspective, New York: Russel Sage Foundation, 1975; ---, Law and Society, New Jersey: Prentice Hall, 1977; W. Friedmann, Legal Theory, London: Steven \& Sons, 1953. 
dibawah panji Islam. ${ }^{5}$ Ekspansi yang demikian cepat ini tentu saja mengandung berbagai resiko dan ketegangan sosial-politik-kultural. Untuk meminimalisir sekian banyak resiko itu dan sekaligus untuk membangun suatu imperium yang besar, kuat dan kokoh, maka diperlukan mekanisme sosialkultural yang mengarah kepada standarisasi acuan normatif-konstitusional dan menuju tahapan homogenisasi yurisdiksi imperial. Tujuan tersebut akan dengan cepat dapat terlaksana jika pengenalan kosakata dan nomenklatur hukum menjadi perhatian utama.

Ketiga, tidak lama sepeninggal Nabi Muhammad terjadi konflik berdarah dan friksi internal di kalangan para sahabat. Friksi ini memuncak dengan munculnya perselisihan politik antara kubu sahabat Ustman Ibn Affan (meninggal/terbunuh thn. 35 hijriah/656 M) dan sayap sahabat Ali Ibn Abi Thalib (meninggal/terbunuh thn. $40 \mathrm{H} / 661 \mathrm{M}$ ).

Pada tahap awal, konflik itu bernuansa sekuler; aliansi dan kompetisi politik berdasarkan garis kekerabatan kemudian dipertajam dengan polarisasi geografis. Tetapi, tidak lama kemudian konflik ini menyeret simbol-simbol keagamaan yang sangat laten. Dalam suasana yang demikian, maka timbul proses sistematisasi doktrin dan pola pemikiran hukum Islam yang diantara misinya adalah untuk memilah dan memilih siapa sesungguhnya yang disebut sebagai orang Muslim yang benar dan siapa yang dapat dikategorikan sebagai orang Muslim yang salah (in-out-grouping).

Keempat, tidak dapat dielakkan bahwa serangkaian ayat al-Quran sendiri menunjukkan secara jelas (qath 'iyyu al wurud wa al-dalalah) misinya untuk membawa perubahan, tidak terkecuali perubahan di dalam bidang hukum. Meski ayat-ayat hukum yang terkandung di dalam al-Quran berjumlah kurang lebih hanya 500 ayat, tetapi dilihat dari gaya bahasa dan implikasi yuridisnya, ayat-ayat itu mengekspresikan substansi normatifnya secara lugas, tegas dan bahkan aksiomatik. Pendek kata, seperti ingin menandaskan adanya kepastian hukum. ${ }^{6}$

Indikasi yuridis ayat itu secara imperatif dapat dimaknai juga bahwa secara positif al-Quran membawa pesan sentral tentang konstruk masyarakat hukum; dimana supremasi hukum (legal supremacy) dijunjung tinggi, dimana

${ }^{5}$ Ahmad Hasan, The Early Development of Islamic Jurisprudence, Islamabad: Islamic Research Institute, 1988, h. 5: Joseph Schacht, The Origin of Muhammadan Jurisprudence, Oxford: Clarendon Press, 1953, h. 15.

${ }^{6}$ Wael, B. Hallaq, A History of Islamic Legal Theories, McGill Institute for Islamic Studies, 1998, hal. 5-15. 
semua orang sama di depan hukum (equality before the law), dimana ikatanikatan etnosentris dan tribalistik dinisbikan diatas prinsip kepastian hukum dan tidak ada kejahatan kecuali ada sanksi dan hukumannya. ${ }^{7}$

Dari sini, tidak mengherankan kiranya bahwa searah dengan kemenangan kelompok legalis Islam, pemikiran Islam tentang moral, sistem dan tata kekuasaan didefinisikan dengan bahasa syariat Islam. Dalam tradisi Sunni, setidaknya hal itu direpresentasikan oleh dua pemikiran tata pemerintahan dan moral kekuasaan Islam; pemikiran al-Mawardi (975-1058 M) dengan karyanya al-Ahkam al-Sulthaniyyah dan pemikiran Ibnu Taymiyah (1263-1328 M) dengan karyanya al-Siyasah al-Syar'iyyah. ${ }^{8}$

Ringkasnya, keduanya menyatakan supremasi syariah diatas institusi kepemimpinan politik. Kepemimpinan politik itu sendiri harus ada dan bertujuan untuk menjunjungtinggi syariah. Dengan ungkapan lain, kepemimpinan politik (khilafah/imamah) itu diwujudkan untuk menggantikan fungsi kenabian dan menjaga agama (al-khilafah maudhu'ah li harasati aldin). ${ }^{9}$

Di zaman sekarang dimana kita memasuki era negara kebangsaan (nation-state), metamorfosa interrelasi yang kuat antara kekuasaan politik dan syariah masih terus berjalan. Munculnya istilah Dar al-Islam, Dar al-Harb atau Dar al-Salam misalnya, adalah perwujudan langsung atau tidak langsung dari kontinuitas simbolik pemikiran real-legalisme al-Mawardi dan Ibnu Taymiyyah.

Memasuki awal abad ke XX dan seiring dengan melemahnya etos intelektualisme Islam serta menguatnya penetrasi dan tantangan kultural, ekonomi dan politik Eropa baru melalui misi perdagangan maupun imperialisme, dinasti Usmaniyyah yang mengusung semangat pan-Islamis (khilafah) runtuh dan menemukan titik balik kehancurannya (tahun $1922 \mathrm{M}) .{ }^{10}$

${ }^{7}$ Ibid.

${ }^{8}$ Lihat, Montgomerry Watt, Islamic Political Thought, Edinburg University Press, 1980; Bassam Tibi, Ancaman Fundamentalisme: Rajutan Islam Politik dan Kekacauan Dunia Baru, Yogya: Tiara Wacana, hal. 3-7; 20-24.

${ }^{9}$ Muhammad az-Zuhayli, Tarikh al-Qadla fi al-Islam, Damascus, Dar al-Fikr alMuashir, 1999, h. 423-436; Colin Imber, Ebus Suud: The Islamic Legal Tradition, Edinburg University Press, 1997, h. 3-64; Subhi Mahmassani, Falsafah al-Tasyri fi al-Islam, transl. Farhat J. Ziadeh, Leiden: EJ.Brill, 1961, h. 39-46.

${ }^{10}$ Nikki R. Keddie, An Islamic Response to Imperialism, Berkeley: Berkeley Univ. Press, 1983: Gershoni dan Jankowski, "Egypt and the Caliphate Question, 1924-1926“ in Egypt, Islam and the Arabs, h. 74. 
Runtuhnya sistem khilafah Islamiyyah dan tidak dimungkinkannya restorasi sistem ini meskipun berbagai usaha telah dilakukan, mengindikasikan sekaligus dua hal; a. dari perspektif geopolitis, runtuhnya sistem khilafah Islamiyyah Usmaniyyah adalah awal dari adanya semangat antitesis khilafah yang bersemangatkan konsep patriotisme geografis di dalam masyarakat Islam sendiri; b. semangat patriotisme geografis ini lambat laun menjelma menjadi semangat nasionalisme dan kedaulatan nasional vis a vis kedaulatan negara asing (kolonial). Di bawah tema nasionalisme, maka masyarakat Islam akan mengikatkan dirinya kepada simbol, kontrak dan konsensus baru di dalam wadah negara-kebangsaan (nation-state) sebagai antitesis dari negara-agama atau negara yang secara rigid diikat oleh nomenklatur syariah.

Dibawah ikatan negara-kebangsaan, maka preferensi untuk mendefinisikan diri secara komunal - mau tidak mau - dinafasi oleh rasa solidaritas sebagai komunalisme bangsa dan rasa pengorbanan sebagai bagian dari ikatan patriotisme geografis. Di dalam wadah negara-kebangsaan, simbolsimbol etno-religio-primordial sedemikian rupa dibatasi kepada tataran kehidupan yang bersifat private dan tidak dibiarkan termanifestasikan di dalam ranah publik (public sphere). ${ }^{11}$

Dalam realitas masyarakat Islam pasca sitem khilafah, tentu saja hal ini memiliki implikasi-implikasi yang serius ${ }^{12}$. Diantara implikasi itu adalah semakin termarjinalisasinya aktualisasi syariah di dalam kehidupan publik, semakin teralienasinya perasaan relijiusitas komunal serta perasaan akan lemahnya ingatan historis kolektif tentang telah berjayanya dinasti-dinasti syariah besar (imperium syariah) masa lalu. Bahkan, psiko-historis ini tidak mustahil menyebabkan masyarakat Islam merasa dalam situasi gamang dan mendesakkan perlunya menemukan pijakan identitas baru yang bersifat defensif, apologetik dan lebih assertif, khususnya terkait dengan simbol, kejayaan dan kontinuitas imperium syariah tersebut. ${ }^{13}$

Dalam konteks Indonesia, dialektika yang demikian sesungguhnya sudah terjadi ketika perdebatan soal dasar negara dan Piagam Jakarta menjelang kemerdekaan atau di dalam Majelis Konstituante di tahun 1950-

${ }^{11}$ Tibi, Ibid.

${ }^{12}$ Michael F. Laffan, Islamic Nationhood and Colonial Indonesia: The Umma Below the Wind, London and New York: Routledge \& Curzon, 2003.

${ }^{13}$ Untuk perbandingan wacana, lihat, Talal Asad, Rethinking About Secularism and Law in Egypt, Leiden: ISIM, 2001. 
an. ${ }^{14}$ Lebih lanjut, karena bagi penjaga dan pembela syariah, terlalu banyak aspek yang dikorbankan di dalam wujud konsensus dan kompromi nasional pada saat-saat yang decisive seperti pada saat diskusi soal dasar negara tersebut, maka --meminjam bahasa syariah-- sudah saatnya dilakukan labelisasi Dar al-Harb untuk Indonesia yang baru merdeka tetapi tidak mengindahkan apa yang mereka anggap sebagai syariah.

\section{Gejala ketidakpuasan politik yang dimanifestasikan oleh Gerakan Kartosuwiryo di Jawa Barat atau Kahar Mudzakkar di Sulawesi Selatan, sedikit banyak memantik emosi bersimbolkan syariah sebagai tema sentral dan titik fokus perjuangan. ${ }^{15}$}

Dialektika, ketegangan, konflik dan konsensus antara yang pro-syariah dan kontra-syariah sepanjang Indonesia merdeka terus terjadi. Runtuhnya rezim Orde Lama di tahun 1966 dan bangkitnya Orde Baru sesudahnya tidaklah menghapus peta sejarah tersebut sama sekali.

Lebih jauh, meski Orde Baru dengan segala cara dan pendekatan politik (tidak jarang dengan pendekatan repressif-militeristik-sentralistik), telah melakukan proses dekonstruksi politik syariah --dengan politik unifikasi hukum nasional serta menekankan pendekatan kesatuan (keikaan) dibanding keragaman (kebinekaan) sebagai bagian dari proses nation-building misalnya-, namun tidak semua model pendekatan itu berjalan efektif. ${ }^{16}$

Sampai batasan tertentu memang Orde Baru berhasil melakukan depolitisasi Islam, unifikasi hukum, dan integrasi keragaman bangsa, serta memisahkan warna 'Islam politik' dan 'Islam kultural'. ${ }^{17}$ Namun, semua itu berjalan hanya dalam kerangka pragmatisme dan secara kamuflatif seolah

${ }^{14}$ Ahmad Syafii Maarif, Islam dan Masalah Kenegaraan: Studi tentang Percaturan dalam Konstituante, Jakarta: LP3ES, 1987; Endang Saifuddin Anshari, Piagam Djakarta 22 Juni 1945, Bandung: Pustaka Salman, 1981.

${ }^{15}$ Lihat, C. van Dijk, Rebellion under the Banner of Islam: The Darul Islam in Indonesia, The Hague: Martinus Nijhoff, 1981; Nazaruddin Syamsuddin, Pemberontakan Kaum Republik: Kasus Darul Islam Aceh, Jakarta: Grafiti Press, 1990; Anhar Gonggong, Abdul Qahhar Muzakkar: dari Patriot Hingga Pemberontak, Jakarta: Grasindo, 1992.

${ }^{16}$ M.B. Hooker, "The State and Sharia in Indonesia 1945-1995", in Indonesia: Law and Society, edited by Tim Lindsey, Sydney: Federation Press, 1999, hal. 97-110; Howard Federspiel, "Islamic Values, Law and Expectations in Contemporary Indonesia" Islamic Law and Society 5, no. 1 (Feb. 1998), hal. 90-117.

${ }^{17}$ Lihat, Bahtiar Effendy, Islam dan Negara: Transformasi Pemikiran dan Praktik Politik Islam di Indonesia (Jakarta: Paramadina, 1998). 
senada dengan kampanye ideologi rezim, (seperti dengan penggalakan program penataran Pedoman Penghayatan dan Pengamalan Pancasila/P4, kampanye politik pelaksanaan Pancasila dan UUD 1945 secara murni dan konsekwen) dan tidak pada tataran fungsional apalagi visioner-normatif. Sehingga, ketika kelak Indonesia memasuki era keterbukaan (reformasi) semua itu seolah cenderung runtuh dan kembali ke titik nol.

Dus, pola manajemen konflik terkait dengan Islam dan negara, keseimbangan antara keragaman dan kesatuan, hubungan pusat-daerah, minimnya apresiasi terhadap nilai dan praktek politik demokratis yang genuine, tidak tersemainya kultur politik humanis-pluralis otentik adalah cacat internal laten bawaan Orde Baru. ${ }^{18}$

\section{Penerapan Syariah, Reformasi dan Penguatan Otonomi Daerah}

Dalam kaitannya dengan penjelasan tentang upaya penerapan syariat Islam di era reformasi ini, hal yang penting untuk diketahui juga bahwa di samping soal hubungan Islam dan negara yang relatif belum terumuskan dengan baku dan dalam kondisi tarik menarik yang terbuka dan demokratis sampai akhir Orde Baru, era reformasi juga mengajarkan bahwa Orde Baru memiliki sejumlah masalah dan akar konflik horizontal maupun vertikal yang serius, seperti; organisasi pola hubungan sipil dan militer yang berkoinsidensi dengan polarisasi politik dan kultural; desentralisasi sistem pemerintahan, politik dan keuangan daerah; keseimbangan struktur ekonomi dan kesejahteraan yang fundamental antara Jawa dan luar Jawa. Dus, semua itu, diantara jawabannya adalah perlunya paradigma baru untuk hubungan pusat dan daerah.

Dengan kata lain, penguatan tuntutan otonomi daerah dan munculnya tuntutan penerapan syariat Islam beriringan dengan semangat demokratisasi. Karena trauma pemberontakan lokal di masa lalu, maka pertanyaan demokratisasi dalam konteks demikian akan dihadapkan dengan beberapa masalah berikut: Pertama, sejauh mana demokrasi nasional dan demokrasi lokal berhasil dikembangkan, dan sejauhmana demokrasi lokal bisa diintegrasikan dalam prosedur demokrasi nasional: Kedua, sejauh mana demokrasi nasional yang dibangun berdasarkan demokrasi local tersebut mampu menciptakan sksistensi masyarakat local secara politik, eokonomi dan

${ }^{18}$ Syamsuddin Haris (ed.), Desentralisasi dan Otonomi Daerah, Jakarta: LIPI, Partnership dan AIPI, hal. 67-69. 
kultural dalam masyarakat politik nasional: Ketiga, sejauhmana menajemen pemerintahan melakukan distribusi sumberdaya ekonomi dan politik lintas lokalitas sehingga tetap relevan untuk mendukung negara-bangsa. Khusus terkait dengan problem penerapan syariah, bagaimana masyarakat dan pemerintah daerah menempatkan agenda ini.

Lahirnya Orde Reformasi di tahun 1998 adalah momen koreksi langsung dari sistem dan pola manajemen konflik Orde Baru tersebut. Sebagai era korektif, Orde Reformasi memberikan banyak peluang dan harapan kepada semua segmen dan kelompok kepentingan, tidak terkecuali para pembela syariah (baca: umumnya pembela Islam politik). Bahkan dalam wujud pendekatan hukum yang lebih konkrit, bergulirnya agenda reformasi juga berarti terbuka kesempatan untuk mengamandemen konstitusi sebagai koreksi kesalahan basis konstitusional di masa lalu. ${ }^{19}$

Politik keterbukaan, koreksi terhadap pola hubungan pusatdaerah/kebijakan desentralisasi, serta demokratisasi tentu saja tidak disiasiakan oleh pembela syariah skripturalis. Desentralisasi melahirkan wacana penguatan otonomi daerah secara signifikan dan -bahkan —otonomi khusus bagi daerah-daerah tertentu.

Otonomi daerah itu sendiri sebenarnya merupakan istilah yang sudah lama. Paling tidak sebenarnya sudah ada lima UU tentang pemerintahan daerah yang bersemangatkan otonomi daerah, meski dengan pengertian yang lebih berorientasi kepada desentralisasi administrative dan bukan desentralisasi politik. Kelima UU itu adalah UU No. 1 Tahun 1945, UU No. 22 thn. 1948, UU NIT No. 44 tahun 1950, UU No. 1 thn. 1957, UU No. 18 thn, 1965, UU no. 5 thn 1974 dan terakhir adalah paket UU No. 22 th. 1999 dan UU No. 25 thn. 1999.

Jika dilihat dari beberapa UU tersebut serta sesuai dengan semangat zamannya maka otonomi daerah itu sebenarnya bukanlah tujuan, melainkan alat dalam rangka mengkonritkan tujuan bernegara yakni cita keadilan untuk semua, demokrasi, dan kesejahteraan rakyat. Kebijakan penguatan otonomi

\footnotetext{
${ }^{19}$ Berganti era akan memberikan kesempatan untuk koreksi konstitusi dan prosedur politik. Hitchner dan Levine mengatakan: "political power is exercised through a series of relationship between the holders of power and the governed. In totalitarian states that power is limited only by the decision of the ruling group and can in principle reach into every area of an individual's life. The power of democratic governments, however, is limited and can be applied only in certain domains and according to known procedures. The framework that defines and limits political power is a constitution". Lihat, Dell G. Hitchner dan Carol Levine, Comparative Government and Politics, New York: Harper \& Row Publishers, 1981, hal. 69.
} 
daerah itu sendiri baru bisa mencapai tujuan dimaksud manakala ia berjalan bersamaan dengan semangat restrukturisasi lembaga perwakilan, sistem pemilihan bagi eksekutif dan legislative, penegakan hukum dan pemberdayaan masyarakat lokal itu sendiri.

\section{SYARIAH, AL-AHWAL ALSYAKHSYIYYAH DAN KEHARUSAN INTERAKSI DENGAN SISTEM HUKUM EMPIRIS}

Interaksi dialektis antara syariah dan realitas kemasyarakatan modern terus perlu dilakukan. Syariah tidak boleh menjadi nilai dan kerangka pemahaman yang memfosil; syariah memiliki daya fleksibilitas dan kreativitas yang tinggi seperti telah ditunjukkan oleh para pemikirnya sepanjang zaman. Ibarat pohon, syariah dapat ditanam dimanapun meski dengan kondisi kesuburan tanah yang berbeda-beda.

Dengan kata lain, dalam konteks negara kebangsaan (nation-state) seperti Indonesia misalnya, syariah dapat berfungsi sebagai substansi nilai yang potensial untuk memberikan akar bagi tumbuhnya ketaatan yang murni (pure legal obedience) dan tulus terhadap konstitusi dan perundang-undangan yang ada. Ia hadir untuk memberikan makna bahwa hidup berbangsa dan bernegara memerlukan ruh, semangat ketulusan, rasa memiliki dan komitmen terhadap konsensus serta keputusan hukum bersama, sebagai kelanjutan dari adanya kedalaman penghayatan dan keterpanggilan yang tumbuh dan berkembang dari pemaknaan hidup yang berdimensi keilahian (religious meaning of life).

Pada keterkaitan pemaknaan yang demikian, maka perangkat dan produk perundang-undangan yang ada bukanlah semata aturan duniawi (profane) yang hanya layak untuk dijadikan acuan kognitif dan otak-atik pengertian semantik perundang-undangan (Begriff und Normwissenschaft) dalam sengketa dan perdebatan teknis-yuridis-formil, tetapi lahir dan ada untuk ditaati dan dijadikan pedoman berdasarkan ketulusan dan kemurniaan prinsip ketaatan. Maka, melalui syariah, manusia Indonesia pada dasarnya dapat diajarkan untuk "hormat konstitusi dan taat kitab suci". (al-Nisa 58-59).

Karena ilmu syariah pada prakteknya juga dapat dimaknai sebagai seperangkat nilai yang sudah dikembangkan sebagai suatu disiplin ilmu, maka teoretisasi dan sejarah pemikiran syariah sudah melahirkan derivasi epistemologis dan teknis keilmuan secara relatif detail. Dikenallah kemudian, 
klasifikasi bidang keilmuan syariah yang dipengaruhi oleh tradisi keilmuan hukum sipil/kontinental (civil law): hukum tentang perseorangan dan keluarga (fiqh al-ahwal al-syakhsiyyah), hukum tentang harta benda (al-ahkam almaliyyah), hukum publik/pidana (al-ahkam al-jinaiyyah) dst.

Sayangnya, karena dualisme tradisi pendidikan (pendidikan umum dan keagamaan) di negara-negara Muslim, maka tradisi keilmuan yang bersifat saling memperkaya dan meminjam antara ilmu-ilmu syariah dan ilmu hukum tidak dapat berkembang. Lebih jauh, secara perlahan-lahan seiring dengan memudarnya tradisi ijtihad, maka proses saling meminjam dan memperkaya itu berubah menjadi tradisi keilmuan dan sikap ilmuwan yang defensif, menolak dan tertutup. Arah dan penajaman spesialisasi keilmuan kemudian lebih menunjang keberlangsungan dualisme tersebut. Dus, tidak mudah untuk mengembangkan keilmuan syariah secara dialektis: saling meminjam dan mengisi diantara keilmuan syariah dan hukum. ${ }^{20}$

Paradoksnya, dalam kenyataan hukum sehari-hari, kontradiksi tersebut sesungguhnya sudah saling mendekat dan mengisi. Praktek hukum dan administrasi hukum yang berjalan di bidang hukum keluarga misalnya, jelas sekali mengindikasikan adanya proses saling mengisi dan meminjam. Hal itu dapat dilihat dari hasil kodifikasi dan unifikasi hukum dalam bentuk Kompilasi Hukum Islam (KHI). Secara obyektif, sebenarnya produk KHI tersebut tidaklah sepenuhnya bersandarkan pada pendapat ulama Sunni empat madzhab. Sistematika, logika hukum, asas dan penalarannya sudah tidak dapat dikatakan sebagai 'murni' merefleksikan hukum Islam konvensional. Hukum prosedurnya/acaranyapun banyak sekali meminjam dari Hukum Acara Perdata (HIR/Rbg) yang diterapkan sejak zaman kolonial Belanda. Maka, jika ditimbang dari aspek pambaharuan hukum sebagai hasil interaksi dinamis dengan hukum-hukum 'non-Islam', sudah terjadi pembaruan internal dan eksternal serta pembaruan silang (intra-extra-inter legal doctrinal reform). ${ }^{21}$

Paradoks yang lain adalah dalam kajian hukum pidana Islam, rujukan utama di berbagai fakultas Syariah ialah buku karangan Abdul Qadir Audah

${ }^{20}$ Ziauddin Sardar, Kembali ke Masa Depan: Syariat Sebagai Metodologi Pemecahan Masalah, Jakarta: Serambi, 2005.

${ }^{21}$ Bandingkan Abdul Wahhab Khallaf, Qanun a l-Ahwal al-Syakhsiyyah, Kuwait: Dar al'Ilm, 1998; R. Kranenburg, De Groundslagen der Rechtswetenschap: Juridischkennis Leer en Methodologie, Zwolle: HD Tjeenk Willink, 1955; Ervin H. Pollack, Fundamentals of Legal Research, Brooklyn: The Foundation Press, 1987; Nell McCormick, Legal Reasoning and Legal Theory, Clarendon Oxford Univ. Press, 1978. 
al-Tasyri al-Jinai al-Islami (Hukum Pidana Islam). Dilihat dari sistematika pembahasan, isu-isu utama yang dibahas dan pendekatan argumen hukum di dalam materi tersebut, maka tidak terlalu sulit untuk berkesimpulan bahwa buku pegangan ini sesungguhnya ditulis dengan gaya, model dan perspektif penulisan buku-buku daras hukum pidana Barat.

Tidak dapat dipungkiri, memang ada problem filosofis dan ontologi keilmuan antara ilmu syariah dan ilmu hukum. Satu contoh saja, dalam ilmuilmu syariah dikenal nilai hukum yang tidak dapat berubah (qathiyyyat). Sementara, dalam ilmu hukum (terutama madzhab Freirechtslehre) nilai hukum itu diciptakan oleh manusia dan sepenuhnya bergantung pada kesepakatan manusia tentang apa yang dianggap sebagai nilai yang berubah dan nilai yang tetap.

Contoh yang lain adalah bentuk sanksi dalam hukum. Dalam pandangan sebagian besar fuqaha, bentuk sanksi dalam tradisi pemikiran hukum Islam sudah final dan tidak ada ruang kreasi manusia di dalamnya. Bentuk itu sudah sedemikian rupa diberikan oleh Yang Maha Kuasa. Sementara, dalam pemikiran pemidanaan dalam perspektif ilmu hukum ( khususnya madzhab empirisme, dan kriminologi), sanksi itu dapat dimodifikasi tergantung pada apakah pijakan pikiran tentang sanksi itu bersifat rehabilitatif atau tekanannya pada pemberian hukuman yang berat dan berupa fisik yang arahnya adalah menimbulkan efek jera bagi si pelaku sekaligus peringatan bagi manusia yang lain (bersifat fisik dan personal).

Dalam perspektif rehabilitatif, maka pandangannya adalah kesalahan individu itu bersifat juga kesalahan kolektif. Manusia mencuri bukan karena semata kesalahan yang bersangkutan, tetapi hal itu juga didorong oleh sistem sosial ekonomi yang 'membuat' dia sebagai pencuri. Dengan demikian, tugas pemidanaan adalah menormalkan kembali si pelaku kejahatan dan tidak fokus hanya pada penjeraan dengan hukuman fisik. Dalam perspektif demikian, tidak ada istilah penjara tetapi yang ada adalah Lembaga Pemasyarakatan (LP). Di sisi lain, sanksi dalam perspektif personal dan fisik lebih memfokuskan pada tindak kriminalitas yang dilakukan adalah kesalahan individu dan hukuman yang diberikan harus berorientasi pada pembebanan fisik untuk pelaku sehingga menimbulkan efek jera baginya dan peringatan bagi 'calon' pelaku. Maka, dalam kerangka demikian, pelaku tindak pidana 
dimasukkan ke dalam penjara atau model hukuman yang lebih didasarkan atas pemberatan sanksi fisik (corporal punishment). ${ }^{22}$

\section{E. NEGARA KEBANGSAAN (NATION-STATE) DAN HUKUM KELUARGA ISLAM ${ }^{23}$}

Seperti disinggung sekilas dalam uraian sebelumnya, bagi orang Islam, sejarah pembentukan negara-negara Muslim (khususnya setelah berhentinya kolonialisme Eropa), tidak dapat dilepaskan dari wacana pembentukan negara sebagai kelanjutan dari motivasi untuk menjunjung norma syariah. Maka, timbullah kemudian problem tentang interrelasi agama dan negara. Problematika interrelasi antara negara dan hukum Islam bukanlah suatu hal yang sama sekali baru jika ditinjau dari ilmu tentang negara atau ilmu tentang hukum (termasuk dalam khazanah studi ketatanegaraan Islam, siyasah syar'iyyah). Dalam khazanah ilmu ketatanegaraan Islam, minimal kita mengenal dua karya monumental; al-Ahkam al-Sulthaniyyah al-Mawardi (975 - 1058 M); dan al-Siyasah al-Syariyyah Ibnu Taimiyah (1263-1328 M).

\footnotetext{
${ }^{22}$ Barda Nawawi, Perbandingan Hukum Pidana, Jakarta: Rajawali Press, 1990; Ade M. Suherman, Pengantar Perbandingan Sistem Hukum, Jakarta; Raja GrafindoPersada, 2004; Pembahasan yang relative dapat membantu pemahaman dengan baik tentang beberapa aspek dari Penelitian Hukum Normatif dapat dilihat; Jhoni Ibrahim, Metodologi Penelitian Hukum Normatif, Malang: Bayumedia Press, 2006.

${ }^{23}$ Beberapa uraian dalam bagian ini, merujuk kepada beberapa sumber; Tahir Mahmood, Family Law Reform in the Muslim World, New Delhi: The Indian Law Institute, 1972;---, Statutes of Personal Law in Islamic Countries: History, Texts and Analysis, New Delhi: The Indian Law Inst, 1995; JM.Muslimin, Islamic Law and Social Change: A Comparative Study of the Institutionalization and Codification of Islamic Family Law in the Nation-States Egypt and Indonesia, unpublished dissertation, Univ. of Hamburg, 2006; John L. Esposito, Women in Muslim Family Law, New York: Syracuse Univ. Press, 1982;---, Islam and Development: Religion and Sociopolitical Change, New York: Syracuse Univ. Press, 1980;Taufik Adnan Amal, Syamsu Rizal Panggabean, Politik Syariat Islam: Dari Indonesia Hingga Nigeria, Ciputat: Alvabet, 2004; W. Dupret, et. al, Legal Pluralism in the Arab World, The Hague: Kluwer International, 1999; Thariq al-Bishri, Fi Masailil Islam al-Muashirah: Baina al-Islam wa al-Urubah, Cairo: Dar el-Shurq, 1998;Rubya Mehdi, The Islamization of Law in Pakistan, Surrey: Curzon Press, Ltd, 1994; Fatimah Mernissi, The Veil and the Male Elite: A Feminist Interpretation of Women's Rights in Islam, Addison: Wesley Publishing Company, 1991; Abdul Wahhab Khallaf, Ahkam al-Ahwal al-Syakhsyiyyah fi al-Syariah alIslamiyyah, Kuwait: Dar el-Qalam, 1990; Qadri A. Fatah as-Sahawi, Mausuat Tasyriat alAhwal al-Syakhsyiyyah, Iskandaria: Mansyaatu al-Maarif, 2001.
} 
Al-Mawardi yang nama lengkapnya adalah Abu Hasan Ali bin Muhammad bin Habib al-Mawardi adalah ulama dari madzhab Syafii, sementara Taqiyyuddin Ahmad Ibn Abdul Shamad Ibn Taimiah adalah ulama madzhab Hanbali. Dari biografinya, al-Mawardi dikenal sebagai hakim dan penasehat istana Abbasiyyah. Sedang Ibnu Taimiyah lebih dikenal sebagai seorang pemikir independen yang dilingkupi oleh kekhawatiran akan terancamnya dinasti-dinasti besar Islam setelah jatuhnya Baghdad ke tangan Mongol (1258 M).

Terkait dengan negara dan hukum Islam, meski al-Mawardi dan Ibnu Taymiyah berbeda madzhab, namun keduanya sepakat bahwa negara Islam (Muslim) harus sepenuhnya terikat kepada hukum Islam dan di dalam negara yang demikian, maka supremasi syariah sebagai sumber dari segala sumber hukum dijunjung tinggi.

Sementara, terkait dengan kepemimpinan Islam yang tunggal, keduanya berbeda: bagi al-Mawardi, kekuasaan Islam itu harus berada dalam satu kepemimpinan (khilafah) tunggal secara multinasional, sedangkan menurut Ibnu Taimiah kekuasaan Islam itu dapat saja terbagi ke dalam beberapa negara dan kepemimpinan (independent state) asal saja mereka merupakan negara yang saling terikat secara misi (semisal bentuk konfederasi/uni/persemakmuran).

Terlepas dari persamaan dan perbedaan yang ada diantara keduanya, jika diteropong dari sosiologi perkembangan pemikiran hukum, maka model pemikiran al-Mawardi dan Ibnu Taimiyah dapat digolongkan ke dalam pemikiran dengan titik tolak pada upaya konservasi kesatuan umat Islam sebagai satu entitas hukum (legal entitiy) di dalam suatu negara. Dengan kata lain, corak pemikiran yang demikian adalah bagian dari cara yuridis demi mengokohkan solidaritas mekanis (mechanical solidarity, i.e, asas personalitas keislaman) berdasarkan syariah.

Model pemikiran hukum dengan pola konservasi solidaritas mekanis demikian menghendaki agar masyarakat diikat oleh suatu aturan norma yang dianggap sebagai nilai bersama yang baku dan tercipta secara ilahi (given) dan final. Selanjutnya, negara diberikan kewenangan dan tugas utama sebagai penjaga nilai-nilai yang dapat menopang tujuan terciptanya solidaritas tersebut (al-din asasun wa al-Imam harisuhu).

Dalam sejarah ketatanegaraan Islam, pemikiran yang demikian dalam kurun waktu yang panjang telah hidup dan dapat dipertahankan. Setidaknya, 
hingga runtuhnya dinasti khilafah Islamiyyah terakhir dan terkuat serta terlama (lebih dari enam abad), yakni Turki Usmani, tahun $1922 \mathrm{M}$.

Runtuhnya dinasti Turki Usmani (1924 M), dominasi kolonialisme Eropa dan kegagalan untuk revitalisasi sistem khilafah, mengindikasikan dengan jelas setidaknya dua hal:

Pertama, dari perspektif geopolitik, bentuk kekhalifahan sebagaimana dipraktekkan oleh dinasti Turki Usmani tidak mungkin lagi dapat berjalan. Seiring dengan itu, muncul perasaan dan ide kebersamaan (solidaritas) yang lebih berorientasi pada patriotisme geografis.

Kedua, menguatnya ide patriotisme geografis lambat laun memunculkan konsep kedaulatan kebangsaan (nasional). Kedaulatan nasional, termasuk di dalamnya kedaulatan hukum, menghendaki adanya kontrak sosialkemasyarakatan dan konsensus sosial yang baru yang --ternyata-- tidak dapat semata-mata didasarkan pada satu doktrin agama yang homogen. Karena heterogenitas masyarakat kebangsaan itu sendiri. Dengan kata lain, lahirlah ideologi nasionalisme dan terciptalah negara dengan pola dan semangat kebangsaan sebagai ganti negara agama (teokrasi) dan semisalnya.

Dalam alur demikian, masyarakat Islam terkonstruksi. Maka, tidak mengherankan kiranya jika realitas yang terjadi hingga sekarang: fenomena negara kebangsaan (nation-state) merupakan bentuk dari mayoritas negaranegara Muslim baru yang berdiri seiring dengan melemah dan lenyapnya kolonialisme Eropa. Negara kebangsaan tersebut diikat oleh standarisasi norma dan nilai yang merupakan derivasi dari semangat dan ideologi nasionalisme.

Dalam prakteknya kemudian, dalam konteks semangat kebangsaan, nasionalisasi hukum secara lambat tetapi nyata berjalan di seantero negaranegara baru tersebut. Sebagai hukum agama yang dikonstruksikan dengan tujuan terciptanya dan terjaganya solidaritas mekanis (mechanical solidarity) dengan pengaturan pola-pola interaksi antar subyek hukum yang telah ditetapkan atau ditafsirkan sebagai bagian dari wahyu, maka hukum Islam mendapatkan tantangan dan menimbulkan kompleksitas persoalan dari dan pada lingkungan makro sosial-politik negara kebangsaan tersebut.

Akibatnya, dalam dinamika negara kebangsaan tersebut, hukum Islam pada aspek pidana (jinayat) adalah hukum yang paling besar mendapatkan tantangan dan paling kecil, sulit, problematis dan rumit kemungkinannya untuk dapat diterapkan. Sementara, hukum personal (al-ahwal al- 
syakhsiyyah) karena bersifat perdata dan secara langsung terkait erat dengan identitas personal-kultural diusahakan untuk tetap bertahan atau direformulasi. Bahkan, mengalami proses positivisasi dengan cara kodifikasi (taqnin) dan institusionalisasi.

Dengan kata lain, sesungguhnya proses kodifikasi dan instititusionalisasi hukum keluarga di dunia Islam tersebut cenderung 'dipaksakan' sebagai agenda islamisasi yang dianggap masih mungkin dalam konteks sosial-kenegaraan yang secara radikal sudah berubah.

\section{F. PEREMPUAN, KODIFIKASI DAN PERUBAHAN HUKUM KELUARGA ISLAM}

Diantara isu sentral dalam kajian Hukum Keluarga Islam adalah bagaimana gambaran tentang peran dan fungsi perempuan yang terefleksikan pada substansi hukum positif di beberapa Negara Muslim. Al-Quran menyatakan bahwa laki-laki dan perempuan setara dan sejajar (al-Hujurat, 13), memiliki kesamaan tanggungjawab personal di akhirat (al-Mukmin, 40), ada timbal balik hak dan kewajiban suami istri dalam rumah tangga (alBaqarah, 228). Di sisi lain, tidak dapat diingkari bahwa ayat-ayat al-Quran juga mengandung pemahaman diskriminatif terhadap perempuan: dinyatakan bahwa laki-laki mempunyai hak waris dua kali lipat dibanding perempuan (alNisa, 11), suami memiliki hak cerai mutlak, sementara istri tidak (al-Baqarah, 226-231. Suami sebagai kepala rumah tangga (al-Nisa, 34), berhak melakukan tindakan preventif dan kursif pra-perceraian (al-Nisa, 34), tidak demikian dengan istri. Suami memiliki kelebihan satu derajat dibanding istri (alBaqarah, 228).

Hadits populer dan praktek sosial kemasyarakatan di zaman Nabi juga cenderung dapat dipahami dengan dua wajah: ada yang cenderung mensetarakan laki-perempuan; adanya dan dibolehkannya perempuan untuk menjadi wiraswastawan/pengusaha (semisal Khadijah); tingginya peran perempuan dalam kepemimpinan keagamaan, seperti peran Hafsah dalam menyimpan mushaf Ustmani (al-Quran); peran Aisyah dalam periwayatan hadist dan kepemimpinannya pada perang Jamal. Tetapi, disisi lain; ada hadist Nabi yang menyebutkan bahwa tidak akan sejahtera suatu kaum jika dipimpin perempuan. 
Dalam perjalanan sejarah superioritas laki-laki ditabalkan lebih jauh oleh mayoritas fuqaha dan mufassirun. Output pemikiran yang demikian dapat dilihat, diantaranya di dalam beberapa kitab fiqh dan tafsir konvensional; seorang suami memiliki hak talak sepihak secara mutlak. Bahkan tanpa alasan yang jelaspun seorang suami boleh menceraikan istrinya. Seorang suami berhak secara mutlak berpoligami. Seorang wali (laki-laki) boleh memaksa perempuan yang berada di bawah perwaliannya untuk menikah dengan lakilaki keinginan sang wali bukan sang perempuan. Kesaksian perempuan di mata hukum setengah dari kesaksian laki-laki, dst.

Lalu, bagaimana gambaran peran dan fungsi perempuan Muslimah di dalam undang-undang positif beberapa negara Muslim?. Berikut sekilas uraiannya.

Diantara isu utama di negara-negara Muslim abad XX yang sering memancing kontroversi dan perdebatan seru adalah pemberlakuan syariah. Termasuk di dalam tema ini adalah pemberlakuan hukum keluarga Islam.

Agenda tersebut diawali secara nyata dengan proses kodifikasi dan institusionalisasi hukum keluarga Islam. Kodifikasi berarti upaya untuk mensistematisir hukum Islam yang tersebar di dalam berbagai pandangan (madzhab) dan buku-buku fiqh yang bercorak normatif-heterogen dan teoritik (nadzariyyat, aqwal al-fuqaha) untuk menjadi suatu teks perundangundangan, layaknya hukum non-agama. Dengan kata lain, bagaimana membahasakan fiqh dalam logika undang-undang.

Sementara, institusionalisasi adalah usaha untuk menegakkan hukumhukum yang terkodifikasi itu (hukum materiil, substantive law) di dalam tata kelembagaan kenegaraan, khususnya pada wilayah yudikatif. Lebih dari itu, institusionalisasi juga dapat diartikan menjadi menegakkan prosedur beracara dalam suatu peradilan. Dengan demikian, institusionalisasi setidaknya terkait dengan hukum ketatanegaraan (konstitusi, politik hukum) dan sekaligus pebentukan hukum ajektif (hukum acara, adjective law) yang dirasakan sesuai dengan hukum keluarga Islam.

Terkait dengan motif dan proses kodifikasi, ada beragam perbedaan di berbagai negara. Di Indonesia misalnya, pada awalnya kodifikasi bertujuan untuk menghindari adanya pluralisme hukum menuju terciptanya proses unifikasi nasional hukum berlandaskan semangat kesatuan kebangsaan. Sementara, di Mesir hukum keluarga memang dipolakan dalam bentuk struktur hukum yang pluralis: dimana masing-masing komunitas agama 
diusahakan untuk memiliki standard acuan hukum tersendiri, meski tetap dalam bingkai konstitusionalisme dan 'demokrasi' kebangsaan.

Sejarah kodifikasi hukum di Indonesia kemudian mencatat, bahwa proses unifikasi hukum keluarga di Indonesia tidak sepenuhnya berhasil. Benar, ada UU No 1 Tahun 1974 tentang perkawinana yang merupakan acuan dari semua warga negara. Tetapi UU ini hanya memuat standarisasi hukum yang bersifat 'mengambang' dan multiinterpretable. Sehingga, dalam prakteknya, untuk warga negara Muslim pada akhirnya Kompilasi Hukum Islam (KHI) lebih banyak berperan. Meskipun, sudah ada UU pokok perkawinan tersebut.

Di pihak lain, unifikasi materi hukum keluarga dengan pola yang demikian tidak berjalan di Mesir. Unifikasi yang ada di Mesir hanya diarahkan kepada unifikasi internal madzhab-madzhab fiqh sunni. Dengan tujuan utama, untuk mencari titik temu diantara madzhab dominan yang ada, khususnya Hanafi dan Syafii.

Lain lagi dengan yang terjadi di Tunisia. Unifikasi hukum perkawinan ditujukan untuk semua warga negara tanpa memandang perbedaan agama. UU Perkawinan di Tunisia berlaku untuk semua warga Tunisia, khususnya setelah dicapai kesepakatan dengan Perancis pada tanggal 1 Juli 1957. Termasuk untuk orang Yahudi sejak tanggal 1 Oktober 1957. Meski untuk kasus-kasus yang sangat spesifik yang belum diatur di dalam UU tersebut, orang Yahudi diperbolehkan untuk berpedoman pada fatwa para Rabbi.

Yang terjadi di Saudi Arabia sama sekali berbeda; tidak ada teks perundang-undangan yang merupakan hasil kodifikasi. Bagi pemerintah Saudi, sampai sejauh ini, al-Quran, hadits dan buku-buku fiqh (terutama madzhab Imam Hanbali) ditambah beberapa fatwa dari ulama 'istana' dirasa cukup untuk menjadi sumber perundang-undangan.

Turki tercatat sebagai negara pertama yang melakukan pembaharuan hukum keluarga dengan lahirnya Ottoman Law of Family Rights tahun 1917. UU ini kemudian menjadi inspirasi bagi gerakan serupa di Lebanon, Yordania, Syria, Mesir dan Irak. Namun, perjalanan sejarah Turki akhirnya menemukan bahwa UU sipil 1926 yang lebih berorientasi model kodifikasi perundangundangan Eropa dirasa lebih tepat diberlakukan. Sehingga, aspek 'formalitas' hukum keluarga Islam tidak lagi menjadi rujukan mutlak. 
Perbedaan model-model unifikasi ini tentu saja tidak dapat dipisahkan dari perdebatan alot di masing-masing negara-bangsa (nation-state) tersebut terkait dengan hubungan antara konstitusi dan hukum Islam. Indonesia lebih memilih model hubungan yang inspiratif dan aspiratif, sementara Mesir lebih memilih kecenderungan kuat hubungan yang bersifat legal-formal, sedangkan Tunisia lebih mengedepankan hubungan keduanya yang bersifat simbolik. Turki lebih memilih hubungan kultural-historis, sementara Saudi Arabia lebih mengedepankan hubungan negara dan agama yang pseudo-teokratis.

\section{G. HUKUM KELUARGA ISLAM DI MESIR DAN PAKISTAN: KESETARAAN GENDER SEBAGAI EFEK SAMPING}

Di Mesir dan Pakistan, khususnya yang menyangkut dengan; (a) masalah pembatasan usia minimal untuk laki-laki dan perempuan yang akan menikah; (b) masalah peran wali dalam pernikahan; (c) masalah pendaftaran dan pencatatan perkawinan; (d) kemampuan ekonomi pra-nikah; (e) masalah hak milik harta benda setelah pernikahan (harta gono gini); (f) masalah poligami dan hak istri; (g) masalah pembatasan hak cerai suami; (h) hak cerai dan akibat hukumnya bagi perempuan; (i) masalah kekerasan di dalam rumah tangga; (j) hak waris bagi keluarga dekat; (k) wasiyah wajibah, terjadi proses penerapan hukum (law enforcement) yang searah: bersifat gradual, eklektik, konservatif dan sejauh mungkin perubahan materi hukum itu tetap berada dalam format relasi kekerabatan patriarkal.

Pasal 149, Konstitusi Mesir pertama (1923) menyatakan Islam sebagai agama negara dan bahasa Arab adalah bahasa resmi. Hal ini tetap ditegaskan kembali pada Konstitusi 1956. Seolah memperkuat posisi Islam dalam tata kelembagaan kenegaraan dan hukum, Konstitusi 1971 menambahkan klausul "prinsip-prinsip syariat adalah salah satu sumber utama legislasi nasional". Lebih jauh, dikarenakan tekanan dari sayap islamis Mesir dan politik akomodasi Anwar Sadat pasca trauma kekalahan perang dengan Israel, maka tahun 1980 klausul itu dipertegas dengan "prinsip-prinsip syariat Islam merupakan satu-satunya sumber legislasi”.

Tahun 1874 Mesir mendapatkan status otonomi dari khilafah Usmaniyyah. Muhammad Qadri Pasya kemudian berusaha untuk menyusun Hukum Keluarga Islam khususnya yang bersandarkan pada madzhab Hanafi. Usaha itu berhasil melahirkan 647 pasal. Meski draft UU inisiatif Qadri Pasya 
tersebut tidak kunjung menjadi UU, namun pasal-pasal tersebut (dilengkapi dengan UU 1883) sangat besar pengaruhnya di dalam praktek peradilan perdata Mesir hingga tahun 1920-an.

Hukum kekeluargaan (perdata) Mesir 1883 dipengaruhi oleh hukum Perancis dan hukum Islam (al-ahwal al-syakhsyiyyah). Hukum tersebut kemudian mengalami berbagai amandemen: tahun 1920 diatur hal baru tentang pengampuan (hadlanah); 1923 tentang usia dalam pernikahan; 1929 tentang beberapa ketentuan di dalam peraturan status personal (al-ahwal alsyakhsyiyyah); 1931 tentang sengketa keluarga dan perceraian; 1943 tentang kewarisan; 1979 tentang poligami dan hak gugat cerai; 1985 tentang poligami dan hak gugat cerai; 2000 tentang peran non-domestik perempuan, pembatalan pernikahan dan hak gugat cerai (khulu').

Sepanjang pasang surut beberapa mandemen terhadap Hukum Keluarga Islam tersebut (khususnya era 1920an dan 1930-an), ide-ide progressif berorientasi pembelaan lansung maupun tidak langsung terhadap hak-hak perempuan yang dikembangkan oleh Muhammad Abduh, Qasim Amin serta beberapa gerakan feminis Mesir, semisal al-ittihad al-Nisai al-Mishri mulai berpengaruh dalam proses legal drafting.

Tahun 1956, seiring dengan politik unifikasi institusional peradilan, Mahkamah Syariah (Peradilan Perdata Islam) dan Mahkamah Millah (Peradilan Perdata Non-Muslim) dibubarkan dan institusi tersebut diintegrasikan dengan Peradilan Sipil. Tahun 1976 dikeluarkan peraturan baru tentang eksekusi putusan pengadilan mengenai nafkah istri, janda, anak-anak dan orangtua.

Dasawarsa 1960-an dan 1970-an adalah era dimana gerakan feminis Mesir secara terus menerus melakukan serangkaian advokasi yang lebih sistematis terkait dengan isu-isu poligami, peran non-domestik perempuan dan hak istri setelah terjadinya perceraian dan penghapusan wewenang wali nikah yang eksessif. Namun, isu-isu tersebut belum menghasilkan perubahan signifikan karena secara langsung bertabrakan dengan pandangan ulama konservatif.

Meski demikian bukan berarti gerakan ide tersebut sia-sia. Sebab, tahun 1979 Presiden Anwar Sadat mengeluarkan dekrit yang berisikan; perlindungan terhadap hak cerai istri, efek kompensasi finansial atas suami terhadap istri setelah perceraian dan pembatasan praktek poligami. Dalam poin hak cerai istri dinyatakan bahwa perceraian akan secara otomatis terjadi 
manakala suami berpoligami. Dekrit ini kemudian dikenal luas sebagai "Undang-undang Jihan". Nama Jihan merujuk kepada istri Anwar Sadat dan perannya di dalam advokasi perundang-undangan tersebut.

Lahirnya UU 1979 tersebut ternyata terus melahirkan kontroversi. Pasca meninggalnya Sadat, tahun 1985 muncul protes dan demonstrasi besarbesaran yang isinya adalah menuntut pemerintah agar menghapus UU tahun 1979. Permintaan tersebut direspon oleh Presiden Husni Mubarak dengan membuat komisi khusus revisi Hukum Keluarga Islam dengan melihat kembali UU 1979, 1920 dan 1929. Akhirnya, di tahun yang sama Husni Mubarak mengeluarkan UU tahun 1985 yang diantara isinya adalah membatalkan proses cerai otomatis karena poligami.

Tahun 1999-2000 perdebatan tentang Hukum Keluarga Islam di Mesir kembali mencuat. Fokus utama perdebatan adalah tentang hukum acara terkait dengan; a. Hak istri untuk bepergian tanpa suami asalkan mendapatkan izin pengadilan; b. Proses perceraian untuk status pernikahan bawah tangan; c. Gugat cerai (khulu'). Poin yang pertama tidak mendapatkan persetujuan parlemen, sementara poin yang kedua dan tiga disetujui.

Perlu dicatat bahwa meski UU terkait dengan personal status (al-ahwal al-syakhsyiyyah) Mesir hanya mengatur tentang aspek keperdataan (hukum keluarga), namun kerapkali berawal dari ketentuan di dalam UU tersebut sebagian gerakan politik Islamis Mesir menemukan celah untuk mendiskreditkan dan melokalisir pengaruh kaum progressif, tidak terkecuali kaum feminis Muslim.

Berangkat dari klausul konstitusional Mesir terkait dengan syariah sebagai satu-satunya sumber hukum nasional, dikombinasikan dengan doktrin hisbah (amar makruf nahyu munkar) dan asas personalitas keislaman di dalam pemberlakuan hukum keluarga Islam, kelompok politik Islamis melakukan class action terhadap Prof. Nasr Hamid Abu Zaid dan Nawal Sadawi.

Abu Zaid didakwa telah murtad karena pikiran-pikiran dan tafsir hermeunetiknya terhadap al-Quran, sementara Sadawi juga didakwa demikian karena pikirannya tentang hak waris laki-perempuan yang harus sebanding. Karena murtad, maka keduanya harus diceraikan dari istri dan suaminya.

Lebih dari itu, dapat dikatakan bahwa sekilas dan diatas permukaan, seolah perubahan dan amandemen yang terjadi menunjukkan progressivitas substantif perundang-undangan hukum keluarga Mesir, namun pada prakteknya (legal practice) hambatan kultural dan struktural masyarakat 
Mesir tidak memungkinkan untuk terus menyuburkan ide-ide feminis di dalam naskah perundang-undangan.

Fakta itu dapat dilihat pada; a. Dalam perundang-undangan Mesir, yang dapat menjadi hakim hanyalah laki-laki. Tentu saja, meski ada ketentuan yang mengatur tentang hak cerai gugat perempuan (khulu'), tetapi pada implementasinya, terjadi atau tidak khulu tersebut, diterima atau tidak gugat cerai tersebut, sangat ditentukan oleh analisa dan interpretasi hakim terhadap fakta dan peristiwa di lapangan. Disini, interpretasi hukum yang patriarkal dan maskulin sangat sering terjadi, sehingga klausul tekstual hukum tersebut tidak dapat dipraktekkan atau telah mengalami bias gender; b. Prosedur beracara di peradilan perdata Mesir membebankan pembuktian pada kasus hak gugat cerai semata-mata kepada istri. Bagaimana mungkin pembuktian itu dapat dilakukan (apalagi harus berdasarkan saksi), karena kasus-kasus hukum keluarga (misal, kekerasan seksual, kekerasan fisik dan psikologis) sering terjadi secara sangat personal dan tidak dapat menghadirkan saksi. Ditambah lagi dengan tingkat pengetahuan dan kesadaran hukum perempuan kelas bawah di desa-desa yang sangat minim; c. Pandangan stereotip kultural relijius yang tetap melekat pada kultur Mesir bahwa istri yang menggugat cerai suami adalah perempuan yang berakhlak buruk dan tidak dapat dipercaya. Stereotip demikian menggiring kepada pendapat publik (lokal) bahwa yang bersangkutan layak untuk diisolasi secara kultural.

Apa yang terjadi di Mesir tidak berbeda jauh dengan kondisi perempuan dan Hukum Keluarga Islam di Pakistan. Sejak berdirinya (3 Juni 1947), Republik Islam Pakistan mengalami kesulitan serius dalam mendefinisikan dirinya. Objectives Resolution (Maret 1949) selanjutnya dijadikan sebagai mukadimah dalam Konstitusi 1956, 1962, dan 1973 serta amandemenamandemennya.

Dalam perjalanan sejarahnya, Republik Islam Pakistan dipenuhi dengan gejolak politik bahkan kekerasan politik; serangkaian usaha kudeta yang berbalas, perseteruan politik akut sampai sabotase dan pembunuhan pemimpin-pemimpin politik.

Tahun 1972, Pakistan Timur memisahkan diri dan berdiri negara Banglades. Kemudian disusun kembali Konstitusi 1973 yang dipandang sebagai konstitusi paling Islami di Pakistan. Dalam konstitusi itu dipertahankan nama Republik Islam Pakistan serta dinyatakan bahwa hukum yang bertentangan dengan al-Quran dan Sunnah tidak boleh diundangkan dan 
hukum-hukum yang ada di Pakistan akan diselaraskan dengan ketentuanketentuan kedua sumber tersebut.

Oktober 1958, melalui suatu kudeta militer Ayyub Khan berkuasa. Setelah melalui kontroversi yang sengit di masanya (1961) diundangkan Ordonansi Hukum Keluarga Islam yang masih berlaku hingga sekarang.

Dilihat dari keseluruhan isinya, ordonansi ini relatif lebih progressif dari sekedar hukum-hukum keluarga Islam yang berserak pada kitab-kitab fiqh ataupun tafsir konvensional; hak-hak perempuan terkait dengan pilihan suami relatif diakui, pernikahan dini bagi perempuan dicegah, hak suami untuk menceraikan istri dengan sewenang-wenang dihindari.

Terkait dengan hak cerai perempuan, pada Bab II poin viii Ordonansi tersebut, disebutkan bahwa perempuan dapat menggugat cerai suaminya dengan alasan mencegah "kerusakan" (darar). Selanjutnya, kondisi "merusak" (darar) tersebut dirinci dengan:

a. suami terbiasa meremehkan dan merendahkan istrinya atau membuat susah kehidupannya dengan perkataan atau perbuatan. Meski hal itu tidak menyiksa secara fisik;

b. menganggap istri sebagai identik dengan perempuan tidak bermoral;

c. memaksa istri untuk hidup dengan cara amoral;

d. menolak kepemilikan istri atau melarang istri untuk menggunakan haknya dalam kepemilikan;

e. merusak komitmen istri terhadap agama dan melarangnya beribadah;

f. beristri lebih dari satu dan memperlakukan istri tidak adil sesuai dengan seruan al-Quran.

Hampir identik dengan perundang-undangan di Mesir, sekilas ada pesan kesetaraan laki-perempuan di dalam aturan tersebut. Tetapi, analisa dan praktek lebih jauh mengindikasikan bahwa; Pertama, banyak pengadilan perdata Pakistan menolak untuk menindaklanjuti laporan dengan menggunakan pasal-pasal tersebut, khususnya yang menyangkut tentang kekerasan di dalam rumahtangga. Alasannya, perceraian itu harus dihindari sesuai dengan perintah Islam. Jadi, dalam kaitannya dengan kekerasan di dalam rumah tangga, pengadilan lebih memilih cara mediatif dan arbritase daripada cara hukum; Kedua, kalau kasus hukum ini (kekerasan di dalam rumah tangga/ terhadap perempuan/istri), diajukan ke pengadilan pidana, pengadilan menolaknya. Pengadilan pidana beralasan; itu bukan perbuatan 
kriminal yang menjadi urusan negara tetapi lebih dianggap sebagai kesalahpahaman individual dan kekeluargaan (perdata). Ketiga, dalam banyak kasus gugat cerai istri karena alasan poligami dan tidakadanya perbuatan adil dari suami, pengadilan hampir selalu mengalami kesulitan untuk membuktikan adil-tidaknya suami.

\section{H. MEMPERBARUI PEMAHAMAN HUKUM KELUARGA DAN MENOLAK PERILAKU MENYIMPANG}

Pengamatan yang lebih seksama mengindikasikan bahwa minimnya praktek hukum yang apresiatif terhadap hak-hak perempuan biasanya dipicu oleh model pembaharuan hukum dan patronase Islamis-umara. Model pembaharuan hukum keluarga biasanya bertumpu pada model intra-doctrinal reform. Yaitu, dengan cara yang lazim disebut dengan metode talfiq: mengabungkan pendapat dua atau lebih madzhab. Baik madzhab populer atau madzhab yang cenderung personal (syadz). Cara lain adalah dengan menempuh pendekatan takhayyur: dengan memilih dan menyeleksi salahsatu pandangan imam madzhab yang lebih kontekstual dan sesuai dengan kebutuhan.

Sementara, dalam konservasi hukum dan patronase sayap politik Islamis-umara, pembaharuan hukum dilakukan dengan metode; extradoctrinal reform. Pendekatan ini cenderung menelaah kasus-kasus hukum dan mengkorelasikannya dengan kemaslahatan publik versi penguasa sehingga melahirkan pendapat hukum yang eklektik dan tidak membahayakan patronase Islamis-umara. Metode yang lazim digunakan adalah dengan memperluas interpretasi serta menelaah kasus-kasus tersebut dengan perspektif maslahah mursalah atau siyasah syariyyah (maqashid al-tasyri).

Dengan demikian, yang menjadi titik temu kepentingan utama Islamisumara adalah: dari kacamata umara yang biasanya lebih cenderung sebagai seorang nasionalis (militeristik-anti-demokrasi) adalah bagaimana mengakomodir tuntuan kaum Islamis tetapi tidak membahayakan secara langsung tatanan sekuler kenegaraan yang despotik. Dari kacamata Islamis, agenda penerapan syariah secara gradual harus tetap ada dan tetap dapat didominasi oleh paham mereka betapapun telah mengalami modifikasi dan kontekstualisasi. 
Dengan kata lain, dalam proses pembaharuan, kodifikasi dan institusionalisai Hukum Keluarga Islam, kepentingan perempuan biasanya masih sebatas dipertimbangkan sebagai "efek samping" dan tidak sebagai "misi utama". Bukti lebih lanjut dari hal ini adalah: di beberapa negara Muslim, relatif sangat jarang disebutkan secara eksplisit di dalam konsideran/naskah akademis UU tersebut: "UU ini bertujuan untuk mengakui adanya kesetaraan dan kesejajaran laki-perempuan".

Melihat skema dan isi dari Hukum Keluarga di beberapa negara Muslim, maka: a. Umat Islam di beberapa negara masih terlalu terbebani dengan doktrin al-Mawardi dan Ibnu Taymiyah terkait dengan relasi agama-negara; b. Karena al-Quran dan hadits berbicara dalam posisi yang ambivalen terkait dengan kesetaraan dan kesejajaran laki-perempuan, ditambah dengan perlakuan umat Islam terhadap al-Quran dan hadits sebagai "Kitab Undangundang" yang tertutup, maka umat Islam tidak bisa membedakan antara tradisi Islam, penafsiran, aplikasi kandungan kitab suci dan hadits yang kontekstual dengan visi dan misi utama kenabian; c. Apresiasi gender dan praktek kesetaraannya tidak dapat dilakukan dengan semata-mata pembaharuan hukum tetapi yang utama adalah: harus tetap digalakkan dengan metode kultural, dialog dan disseminasi. Dalam hal ini (bisa jadi yang paling mungkin) berlaku kaedah: perubahan dimulai dari budaya dan akan merambah ke hukum. Bukan sebaliknya; d. bagaimanapun, satu hal yang patut dicatat sebagai hikmah dari adanya dialektika pembaruan pemahaman Hukum Keluarga Islam seperti tersebut di atas: di satu sisi Hukum Islam tidak dapat dijadikan alat untuk proses radikalisasi agama (karena kesediaannya untuk berdialog dengan isu kontemporer:gender, hak asasi manusia dll.). Di sisi lain, Hukum Keluarga Islam masih tetap mampu untuk secara preventif menolak dan mencegah agar umat Islam tetap memiliki basis keluarga yang dapat dijadikan lembaga yang efektif untuk menolak perilaku serba boleh: kekerasan seksual, penelantaran anak, poligami yang sewenang-wenang, kecenderungan perilaku seks ala kelompok lesbianis, gay, bisex dan transjender.

\section{PENUTUP: INOVASI KAJIAN HUKUM KELUARGA ISLAM, KETERBUKAAN DAN PENYIMPANGAN PERILAKU}

Bekal kajian di perguruan tinggi adalah pilar utama untuk ide kajian dan atau sekaligus penerapan syariah. Seperti yang kita alami di dunia perguruan 
tinggi, jika kita membagi kajian dan penelitian hukum ke dalam dua kategori (normatif-empiris), maka arah dan bekal pengkayaan untuk kajian maupun aplikasi syariah (Hukum Keluarga Islam) agar berlangsung dialogis dan substantif (sekaligus mencegah radikalisasi agama dan perilaku menyimpang), dapat dimulai dengan bekal kajian yang berpola sebagai berikut: $^{24}$

I. Studi tentang Hukum Keluarga Islam dalam relasinya dengan fungsi kelembagaan sosial. Hal ini mencakup, diantaranya; a. Kaidah sosial hukum Islam, kaidah hukum Islam murni dan kaidah hukum publik (kenegaraan) Islam dan kaidah Hukum Keluarga Islam; b. Hukum Keluarga Islam dan model serta bentuk sanksinya sebagai proses kontrol sosial dan soliditas solidaritas mekanik umat Islam; c. Lembaga pembentuk, penegak dan penerapan Hukum Keluarga Islam serta perannya dalam islamisasi hukum dan politisasi Islam sekaligus; d. Aneka profesi pengemban Hukum Keluarga Islam dan pendidikannya; e. Perempuan, Anak dan Hukum Keluarga Islam; f. Pengembangan profesi yang terkait dengan Hukum Keluarga Islam Kontemporer.

II. Studi tentang Hukum Keluarga Islam sebagai bagian dari proses ketegangan dan konflik dengan realitas. Hal ini mencakup, diantaranya; a. Filosofi ketaatan dalam Hukum Keluarga Islam dan faktor sosial untuk efektifitasnya; b. Proses formalisasi Hukum Keluarga Islam untuk menjadi hukum negara dalam bingkai hukum sekuler; c. Hukum formil, Hukum Keluarga Islam dan perilaku yudisial dalam kerangka resolusi konflik dan upaya untuk mencapai keadilan; d. Hukum Keluarga Islam dan evolusi serta revolusi sosial; e. Hukum Keluarga Islam, hak-hak asasi manusia, konstitusionalisme dan demokrasi.

III. Studi tentang Hukum Keluarga Islam di tengah-tengah perubahan sosial. Hal ini mencakup, diantaranya; a. Hukum Keluarga Islam sebagai realitas sosial dalam proses reformasi sosial; b. transformasi nilai Hukum Keluarga Islam dari norma dan nilai yang hidup (living law) tetapi tidak terstruktur menjadi hukum nasional; c. Hukum Keluarga Islam sebagai realitas yang hidup dan

${ }^{24}$ Bandingkan dengan Soetandyo Wignjosubroto, Hukum, Paradigma, Metode dan Dinamika Masalahnya, Jakarta: Elsam \& Huma, 2002, hal. 56-58. 
transaksi sosial menuju konsensus; d. Modernisasi dan pergeseran nilai Hukum Keluarga Islam; e. Hukum sebagai realitas dan proses transplantasi kultural; f. Hukum Keluarga Islam dan negosiasi damai dengan globalisasi nilai.

IV. Studi Perbandingan Hukum Keluarga Islam dan Hukum Perdata lainnya. Hal ini mencakup perbandingan konsep, substansi dan struktur hukum; Pola-pola sinkronisasi asas hukum secara vertikal dan horizontal; Kaidah-kaidah Dasar Perbandingan Hukum Perdata dan Hukum Keluarga;

V. Hukum Keluarga Islam dan aneka metode ilmu-ilmu kenyataan hukum (realwissenschaft). Hal ini mencakup, diantaranya; a. Teori-teori struktur sosial masyarakat dan keluarga Islam dan kaitannya dengan ilmu-ilmu kenyataan hukum; b. Teori-teori gejolak dan konflik nucleus family dan masyarakat Islam serta keterkaitannya dengan hukum kebendaan; c. Hukum Keluarga Islam sebagai kristalisasi norma solidaritas mekanis; $\mathrm{d}$. Kepemilikan dan kekerabatan; e. Variasi kombinasi dan konvergensi nilai dalam keluarga Islam; d. Sekularisasi radikal versus fundamentalisme Hukum Keluarga Islam radikal serta dampaknya.

Wallahu a'lam bi al-shawab

\section{DAFTAR PUSTAKA}

Abdul Wahhab Khallaf, Qanun a l-Ahwal al-Syakhsiyyah, Kuwait: Dar al'Ilm, 1998

Abdul Wahhab Khallaf, Ahkam al-Ahwal al-Syakhsyiyyah fi al-Syariah alIslamiyyah, Kuwait: Dar el-Qalam, 1990

Abdurrahman al-Muala "Crimes and Punishment in Islam", www.islamtoday.com, last modified 16 oct 2011

Ade M. Suherman, Pengantar Perbandingan Sistem Hukum, Jakarta

Ahmad Hasan, The Early Development of Islamic Jurisprudence, Islamabad: Islamic Research Institute, 1988, h. 5: Joseph Schacht, The Origin of Muhammadan Jurisprudence, Oxford: Clarendon Press, 1953, h. 15 
Ahmad Syafii Maarif, Islam dan Masalah Kenegaraan: Studi tentang Percaturan dalam Konstituante, Jakarta: LP3ES, 1987

Anhar Gonggong, Abdul Qahhar Muzakkar: dari Patriot Hingga Pemberontak, Jakarta: Grasindo, 1992

Bahtiar Effendy, Islam dan Negara: Transformasi Pemikiran dan Praktik Politik Islam di Indonesia (Jakarta: Paramadina, 1998)

Barda Nawawi, Perbandingan Hukum Pidana, Jakarta: Rajawali Press, 1990

Bassam Tibi, Ancaman Fundamentalisme: Rajutan Islam Politik dan Kekacauan Dunia Baru, Yogya: Tiara Wacana, hal. 3-7; 20-24

Colin Imber, Ebus Suud: The Islamic Legal Tradition, Edinburg University Press, 1997, h. 3-64

C. van Dijk, Rebellion under the Banner of Islam: The Darul Islam in Indonesia, The Hague: Martinus Nijhoff, 1981

Dell G. Hitchner dan Carol Levine, Comparative Government and Politics, New York: Harper \& Row Publishers, 1981, hal. 69

Endang Saifuddin Anshari, Piagam Djakarta 22 Juni 1945, Bandung: Pustaka Salman, 1981

Ervin H. Pollack, Fundamentals of Legal Research, Brooklyn: The Foundation Press, 1987

Farhat J. Ziadeh, "Criminal Law" in The Encyclopedia of the Islamic World.

Fatimah Mernissi, The Veil and the Male Elite: A Feminist Interpretation of Women's Rights in Islam, Addison: Wesley Publishing Company, 1991

Howard Federspiel, "Islamic Values, Law and Expectations in Contemporary Indonesia" Islamic Law and Society 5, no. 1 (Feb. 1998), hal. 90-117

JM.Muslimin, Islamic Law and Social Change: A Comparative Study of the Institutionalization and Codification of Islamic Family Law in the Nation-States Egypt and Indonesia, unpublished dissertation, Univ. of Hamburg, 2006

Jhoni Ibrahim, Metodologi Penelitian Hukum Normatif, Malang: Bayumedia Press, 2006

John L. Esposito, Women in Muslim Family Law, New York: Syracuse Univ. Press, 1982

Lawrence M. Friedmann, The Legal System: A Social Science Perspective, New York: Russel Sage Foundation, 1975

Lawrence M. Friedmann, Law and Society, New Jersey: Prentice Hall, 1977 
Marshall G.S. Hodgson, The Venture of Islam, Chicago: The University of Chicago Press, 1974, Vol. 1, hal. 117-118

Matthew Lipman "Islamic Criminal Law and Procedure: Religious Fundamentalism vs Modern Law" in Boston College of International and Comparative Law Review, vol. 12, Issue 1, 12-1-1989

Michael F. Laffan, Islamic Nationhood and Colonial Indonesia: The Umma Below the Wind, London and New York: Routledge \& Curzon, 2003

Montgomerry Watt, Islamic Political Thought, Edinburg University Press, 1980

Muhammad az-Zuhayli, Tarikh al-Qadla fi al-Islam, Damascus, Dar al-Fikr al-Muashir, 1999, h. 423-436

M.B. Hooker, "The State and Sharia in Indonesia 1945-1995", in Indonesia: Law and Society, edited by Tim Lindsey, Sydney: Federation Press, 1999, hal. 97-110

Nazaruddin Syamsuddin, Pemberontakan Kaum Republik: Kasus Darul Islam Aceh, Jakarta: Grafiti Press, 1990

Nell McCormick, Legal Reasoning and Legal Theory, Clarendon Oxford Univ. Press, 1978

Nikki R. Keddie, An Islamic Response to Imperialism, Berkeley: Berkeley Univ. Press, 1983: Gershoni dan Jankowski, "Egypt and the Caliphate Question, 1924-1926" in Egypt, Islam and the Arabs, h. 74.

Nurcholish Madjid, Islam: Doktrin dan Peradaban, Jakarta Paramadina, 2000

Qadri A. Fatah as-Sahawi, Mausuat Tasyriat al-Ahwal al-Syakhsyiyyah, Iskandaria: Mansyaatu al-Maarif, 2001

Rubya Mehdi, The Islamization of Law in Pakistan, Surrey: Curzon Press, Ltd, 1994

Rudolp Peter, Crime and Punishment in Islamic Law: Theory and Practice from the Sixteenth to the Twenty-first Century, UK: Cambridge Univ. Press, 2005

R. Kranenburg, De Groundslagen der Rechtswetenschap: Juridischkennis Leer en Methodologie, Zwolle: HD Tjeenk Willink, 1955

Soetandyo Wignjosubroto, Hukum, Paradigma, Metode dan Dinamika Masalahnya, Jakarta: Elsam \& Huma, 2002, hal. 56-58.

Subhi Mahmassani, Falsafah al-Tasyri fi al-Islam, transl. Farhat J. Ziadeh, Leiden: EJ.Brill, 1961, h. 39-46 
Syamsuddin Haris (ed.), Desentralisasi dan Otonomi Daerah, Jakarta: LIPI, Partnership dan AIPI, hal. 67-69.

Tahir Mahmood, Family Law Reform in the Muslim World, New Delhi: The Indian Law Institute, 1972

Tahir Mahmood, Statutes of Personal Law in Islamic Countries: History, Texts and Analysis, New Delhi: The Indian Law Inst, 1995

Talal Asad, Rethinking About Secularism and Law in Egypt, Leiden: ISIM, 2001.

Thariq al-Bishri, Fi Masailil Islam al-Muashirah: Baina al-Islam wa alUrubah, Cairo: Dar el-Shurq, 1998

Taufik Adnan Amal, Syamsu Rizal Panggabean, Politik Syariat Islam: Dari Indonesia Hingga Nigeria, Ciputat: Alvabet, 2004

Wael, B. Hallaq, A History of Islamic Legal Theories, McGill Institute for Islamic Studies, 1998, hal. 5-15

W. Dupret, et. al, Legal Pluralism in the Arab World, The Hague: Kluwer International, 1999

W. Friedmann, Legal Theory, London: Steven \& Sons, 1953

Ziauddin Sardar, Kembali ke Masa Depan: Syariat Sebagai Metodologi Pemecahan Masalah, Jakarta: Serambi, 2005 